\title{
Factors Influencing ICT Integration in Resource Planning In Secondary Schools in Mashuuru District, Kajiado County, Kenya
}

\author{
Asibah Everlyne M Kerubo, Dr Rose Obae, Ferdinand Mbeche, Joseph Ndung'u Karanja
}

\begin{abstract}
This study sought to investigate factors influencing ICT integration in resource planning in secondary schools in Mashuuru district, Kajiado County. Specifically, the study sought to determine the influence of teachers' perception and establish the influence of principals' age, all in the integration of ICT in resource planning in secondary schools. The study employed descriptive survey design with both qualitative and quantitative approaches targeting 13 secondary schools, 13 school principals and 226 teachers. A sample of 88 respondents was randomly selected to participate in the study, while 13 principals were purposefully selected and interviewed for argumentation purposes of the study findings. From the findings it revealed that the respondents had moderate positive perception towards the ICT integration in resource planning in schools. Teachers perceived that ICT saves time, helps them accomplish many tasks within a short time, eases lesson preparation, teachers generally like it, is efficient in producing reports, it is not hectic nor complicated to use and helps them accomplish much within a short times with a mean level of 3.28 , 3.23,3.22, 3.11, 3.08, 2.82 and 2.80 respectively. The average mean was 3.08 implying a moderate level of positive perception among the teachers on the use of ICT in the resource planning of the school. The regression model's adjusted R-squared was 0.043 , in which explains $(4.3 \%)$ of the teachers perception factor influencing integration of ICT in resource planning. The regression model's adjusted $\mathrm{R}$ - squared was 21.9 as which explains $(21.9 \%)$ of the resource planning as influenced by the age of the schools principals as an independent variable. This therefore, explains $(\mathbf{2 1 . 9 \% )}$ of the Principals' age factor affecting ICT integration in resource planning. Hence, the remaining (36.9\%) should be explained by other factors not captured in this study. The study concluded that influence of teachers' perception on ICT integration in resource planning and Principals' age greatly influence the integration of ICT in resource planning in secondary schools. It was concluded that teachers, school managers, the education officials and the government should work hand in hand to make sure that ICT infrastructure are availed and the staff gets adequate training in order to enhance ICT integration in resource planning in secondary schools.
\end{abstract}

Index Terms - ICT Integration, Information science, resource planning, software packages, financial, administrative and instructional management.

Asibah Everlyne M Kerubo, Department of Education Administration and Planning, University of Nairobi

Dr Rose Obae, ,Dr Rose Obae (Senior Lecturer), Department of Education Administration and planning University of Nairobi, kikuyu campus, Kenya. Ferdinand Mbeche, Ferdinand Mbeche (Department of Education Administration and Planning, University of Nairobi)

Joseph Ndung'u Karanja, Department of Education Administration and Planning University of Nairobi

\section{INTRODUCTION}

There was evidence from developed countries that investment in ICT in education planning in schools has had a significant impact [1] As a region lagging behind in integration, use and innovation in the ICT sectors, its people were missing out on a better education and well managed education systems and entities. Indeed, majority of sub-Saharan Africa's populations were missing out on the tools of ICT in resource management in schools [2]. However, East African countries hardly use ICT to manage the quality of output, or to raise teacher productivity, or to reduce costs through analyzing spending. This was attributed to a myriad of challenges facing most schools in this region with regard to integration of ICT in educational planning. This resulted to a slow rate of integration of technology despite its promise and potential for use in educational planning in schools [3].

It was true that since the turn of the $21^{\text {st }}$ century, the Kenyan Government have been working towards the realization of transforming all educational institutions in the country to be ICT compliant as attested by the interest shown on ICT in a number of government policy documents [4]. Amidst this favorable gesture from the Government of Kenya to embrace ICT, studies suggest that integration and use of ICT in schools across the country have not been automatic. The effective implementation of ICT in schools was a multifaceted, complex process that just not involves providing the technology to schools but also involves teachers' competencies, schools readiness, long term financing and curriculum restructuring, among others [5]. From early 1990s, increasing numbers of secondary schools in Kenya acquired computers for use in the institutions. The initiatives were partly due to pressure from parents, communities and politicians. Some of the computers installed in these schools came in the way of donations [6]. Despite the central role occupied by administration in the schools, for a long time there has been little emphasis on the effectiveness of ICT goals in the Kenyan schools.

The emergence of ICT has become a driving force for educational reforms, making it possible for school managers, staff, students and parents to exchange information and ideas ease and instantly. This has been witnessed in number of schools having websites and confirmed by [7] who affirmed that to assess level of ICT use in education in Kenya, noted that schools are integrating ICT in planning of finances, co-curricular activities and infrastructure and human 
resources management. [8] asserted that ICT enhances day-to-day planning of institutions and enables schools to improve in efficiency and cope with rapidly changing world in executing management tasks. In support of this contention [9] notes that cost-effective application of ICT related technology combined with flexibility in learning and administrative activities is essential in enhancing efficiency in secondary schools.

In Kenya, the government encourages use of ICT as a tool to revolutionize management in schools to enhance more effective organizational structures and create a stronger links with the community and empower learners with skills necessary for independent learning. Through the Ministry of Education, Science and Technology (MOEST), the government of Kenya has provided a policy base for integration of ICT in education and training to enable learners and institutional managers to cope with management challenges arising from technological improvement and globalization [9]. Schools in Kenya have integrated ICT computers as technical subject and not integrated its use in school resource planning. The use of ICT in educational planning was greatly under-emphasized [10]. As such, a more holistic approach requires that schools be receptive and open to the changes ICT may make, and to the ongoing evaluation of these changes for the schools' purposes. Principals need to have basic information on quality of teaching, student and teacher in order to make the most basic resource allocation decisions [11].

As a matter of fact, schools in Kenya where ICT has been integrated have only adopted computers as technical subject and not integrated its use in school management. The use of ICTs in educational management is greatly under-emphasized [12]. As such, a more holistic approach requires that schools be receptive and open to the changes ICTs may make, and to the ongoing evaluation of these changes for the schools' purposes. Educational managers need to have basic information on quality of teaching, student and teacher flows, probably also of school supplies, and how much the school as a system is spending on various inputs, in order to make the most basic resource allocation decisions. As such, this paper examines the challenges affecting the integration of ICTs in education planning in schools in Kajiado County

\section{A. STATEMENT OF THE PROBLEM}

Most of the meetings held in Mashuuru Sub county had experienced wastage of time in tracing the previous records, a times missing records as a result of misplacing them. These were as a result of handling records in manual sheets which get lost each and every time. The sub county being located in a semi arid area, some donors from Non-Governmental organizations had played a great role in providing Computers in some of the school. According to Mashuuru district inspection report carried out on $20^{\text {th }}$ March, 2014 there were a problem of record keeping, the files with confidential information were nowhere to be seen. The principals who had integrated ICT had kept their documents safe and were easily accessible. During their General annual meeting on $10^{\text {th }}$ October 2014 by the District Education Board (D.E.B.) most principals could not present their Human resource planning details in schools in power point form apart from the few who had integrated ICT in their schools. Due to this, the researcher decided to investigate the problem.

\section{B. PURPOSE OF THE STUDY}

The purpose of the study was to investigate factors influencing ICT integration in Resource Planning in secondary schools in Mashuuru district, Kajiado County.

\section{OBJECTIVES OF THE STUDY}

This study was set to establish the following objectives:-

1. To determine the influence of the teachers' perception of ICT in the integration of ICT in resource planning in schools.

2. To establish the influence of principal age and the integration of ICT in resource planning in schools.

\section{RESEARCH QUESTIONS.}

The objectives were guided by the following research questions;

1. How did teachers' perception influence the integration of ICT in resource planning in schools?

2. To what extend did the principal age influence the integration of ICT integration of resource planning in schools?

\section{E. HYPOTHESIS OF THE STUDY}

$>$ Secondary schools teachers have positive perception of ICT in the integration of ICT in resource planning.

> Principals' age is one of the key determinants in integration of ICT in resource planning in secondary schools.

\section{F. SCOPE OF THE STUDY}

The study delimited itself by concentrating on factors influencing ICT integration on Resource planning in secondary schools in Mashuuru district. This was because ICT had numerous applications at different levels of education as well as wide range of use in virtually all aspects of life which cannot be covered under one study. Mashuuru district had individual private schools, mission private schools and public secondary schools. The respondents of this study were teachers and principals from both public and private secondary schools.

\section{LITERATURE REVIEW}

\section{A. INTRODUCTION}

There is plethora of literature on ICT, but there is scarcity of literature exclusively focusing on the influence of ICT in the performance of science subjects especially in Kenya secondary schools. This chapter summarizes the information from the available literature in the same field of study. It is important to note that integration of ICT into the resource planning process in schools is not an initiation independent process but it enormous resources in terms of facilities and human capacity as well as participation of all the stakeholders. This section discusses the integration of Information 
Communication and technology, teacher training in integration of ICT in resource planning, principals' age in integration of ICT in resource planning, teachers' perception in integration of ICT in resource planning, summary of literature, theoretical framework and conceptual framework.

\section{B. HISTORY OF ICT INNOVATION IN SCHOOL PLANNING}

Though many people believe and perceive ICT to be a new phenomenon, history has shown that humans have been storing, retrieving, manipulating and communicating information during the times of Sumerians of Mesopotamia [13]. The term information technology was first used and appeared in a 1958 in the Harvard Business Review [14]. The proponents of ICT terminology in the business and management world were Leavitt and Whisler whose work appeared in 1958 [15]. Based on the storage and processing technologies employed, it is possible to distinguish four distinct phases of IT development: pre mechanical (3000 BC-1450 AD), mechanical (1450-1840), electromechanical (1840-1940) and electronic (1940-present) [16]. The first and earliest mechanical analogue computer (geared mechanism) referred to as the Antikythera mechanism was used at the beginning of the first century [15].

However, it was not until 1645 when the first mechanical calculator capable of performing the four basic arithmetical operations was developed. It was not until 1940s when electronic computers, using either relays or valves began to appear for use in business and as a tool for planning of organizations with electromechanical [17] completed in 1941 as the world's first programmable computer, and by modern standards one of the first machines that could be considered a complete computing machine. The potential of information communications technology (ICT) to enhance human capabilities and revolutionize the planning of organizations was first realized in other sectors of human society, mostly in the business world and the military, other than in education [18]. The importance of ICT contribution is also widely recognized both in the workplace and at home [14]. Through the pledges by the current president and deputy president of Kenya during their campaigns, the teaching of Computer literacy is supposed to commence in standard one in all Kenyan primary schools. These examples are just a few pointers which show that ICT is becoming a vital enabling tool that can no longer be ignored in the planning of resources of schools.

\section{THE USE OF ICT IN THE RESOURCE PLANNING SCHOOLS}

According to [19] as an aspect of financial planning and control, budgeting process in schools requires the availability of multiple sources of information to cope which can best availed through incorporation of ICT in school planning and management systems. Budgetary allocations as aspects of budgeting process in school management are intricate processes requiring reliable, timely, user-friendly information for supporting planning decisions. [20] revealed that heads of secondary schools have utilized technology in planning and control in financial planning, which greatly improved discipline in resource management.

[21] explained how the ability connects computers through networks helps principals to work together and share information and thus promoting school-community relationship. For ICT integration programs to be effective and sustainable, administrators themselves must be competent in the use of the technology, and they must have a broad understanding of the technical, curricular, administrative, financial, and social dimensions of ICT use in education [22].

\section{BENEFIT OF ICT IN EDUCATIONAL PLANNING}

Usage of ICT in administrative planning involves harnessing technology for better planning, setting standards, effecting change and monitoring results of the core functions of secondary schools. According to [23], ICT is used in maintenance of records, communication and documents planning. A study carried by [24] in South Eastern States, Nigeria noted that influence of ICT on planning and management systems have changed nature of administration in secondary school by allowing information to be transferred, stored, retrieved, and processed by almost all who work, study or interact within and outside the institutions. This according to [16] has improved efficiency in day-to-day school operational activities especially in managing information about students, staff and resources. Based on this realization [25] asserted that integration of ICT into secondary administrative processes enhance overall schools records by making it more accessible to many within a short time.

According to [26], the same elements of computing and telecommunications equipment and service that have made businesses more efficient and cost-effective can be applied to schools and educational systems. ICTs can help school administrators and school principals to streamline operations, monitor performance and improve use of physical and human resources [27]. More than other technologies, computer related technologies have the potential to support the planning of complex, standards-related instructional processes in relatively simple ways. They can also promote communication among schools, parents, central decision makers and businesses thus fostering accountability, public support, and connectivity with market place [28].

\section{E. INTEGRATION OF INFORMATION COMMUNICATION AND TECHNOLOGY IN RESOURCE PLANNING IN SCHOOLS}

In recent times, there has been intense advocacy both nationally and internationally for the integration of ICT in secondary schools [29]. [30] observed that integration of ICT in the school is to enhance better planning and management of schools. It ensures transactional institutional communication where the teachers and school managers managed the human materials, time and space to make sure that school activities run well.

In Kenya, improved secondary education is fundamental to the creation of effective human capital. Secondary school education system is the most strategic education sector and unfortunately the least developed and the least available. With the vision of changing planning and management paradigms in Kenya, the introduction of ICT in schools 
initiatives aim to tackle the problems of secondary education in the country through the application of ICT. However, a successful exploitation of the potential of ICT for the enhancement of secondary education depends more on pedagogical and inter-organizational strategies than ICT issues [31].

\section{F. TEACHERS' PERCEPTION OF ICT AND ICT INTEGRATION IN RESOURCE PLANNING}

Teachers' Perception towards new technologies in secondary schools and its effects in integration and use shows that if teachers perceive use of ICT as either satisfying their own needs or their students' needs, it is likely they would implement it in school. Attitude is brought about by other factors like teachers' competency, skills, knowledge and perception towards ICT [11]. Research suggests that teachers' Perception influence successful implementation of ICT in schools [5]. If teachers' perceptions are positive toward use of ICT, then they can easily use it or provide useful insight about its implementation [32].

A survey by EU School net in 2010 [33] involving teachers' use of ICT in six European Union countries, revealed that a large number of participants perceived use of ICT had positive impact on their learning, elicited interest, promoted individualized learning and helped to lengthen study beyond school day. However, a study by [34] suggested that small number of teachers perceived benefits of ICT in schools were not clearly identified. Some teachers viewed ICT as waste of time and expensive.

A similar study by [33] revealed that teachers' skills, perception and attitudes were related to their use of ICT in resource planning. The more skilled teachers are in ICT, the more likely they were to use it. Further study by [35] revealed that positive attitude, personal entrepreneurship and computer experience had a direct positive influence on adoption and use of ICT by teachers. [36] points that for successful transformation of school practice; teachers need to develop positive attitudes toward innovations. [24] argued that positive computer attitudes by teachers are expected to foster implementation of ICT in schools. Further study by [37] on teachers' attitudes towards computer use in Singapore found that teachers were more positive about their attitude towards computers and intention to use them, than the helpfulness of computer towards other use. These studies reveal that teacher's skills, perceptions, and attitudes influence adoption and use of ICT in schools.

\section{G. PRINCIPAL AGE AND INTEGRATION OF ICT IN RESOURCE PLANNING}

Teachers' age influenced the integration of an innovation. The report by the National Center for Education Statistics indicated that teachers with fewer years of experience were more likely to use computers in their classes than teachers with more years of experience. Studies by [2] indicated that more specifically, teachers with less teaching experience use computers more than teachers with long teaching experience. This may be due to the fact that new teachers have been exposed to computers during their training and therefore, have more experience using this tool [38].

Moreover, [39] investigated about age differences in the overlooked context of individual integration and sustained usage of technology in the workplace using the Theory of Planned Behavior (TPB). They studied on user reactions and technology usage behavior over a 5-month period among 355 workers being introduced to a new software technology application. The results showed that the decisions of younger workers were more strongly influenced by their attitude toward using the new technology. In contrast, older worker were more strongly influenced by subjective norm and perceived behavioral control. Then, these groups of people adopt very different decision processes in evaluating new technologies. On the other hand, [40] found that age was not a significant factor in relation to teachers' attitudes towards ICT.

In addition, [41] carried out a study about technology integration in the schools. They used a qualitative study to examine the classroom practice of 30 "tech-savvy" teachers who used computer technology in their instruction. They found that teachers, who were new and skilled with technology, were innovative and adept at overcoming obstacles, and that they did integrated technology on a consistent basis as both a teaching and learning tool. The authors above agree with the results of study [30] that the probability that teachers would use ICT in the classroom was limited by the reality that teachers who were educated 20 years ago were trained by people who themselves were trained before the arrival of computers in schools.

\section{METHODOLOGY}

\section{A. RESEARCH DESIGN}

Research design is the structure of any scientific work that gives direction and systemizes the research. This study adapted descriptive survey design. According to [42] is a method of collecting information by interviewing or administering questionnaire to a sample individual. A descriptive survey design with both qualitative and quantitative methods was adopted. The advantages of combining qualitative and quantitative techniques in research were given by [43] who pointed out that these methods triangulate and complement the results obtained from each of these approaches and minimizes the methodological problems that result from the weaknesses inherent in any of the research designs.

\section{B. TARGET POPULATION}

Target population is a group of people that is identified as the intended participant for research. The target population for this study involved 13 secondary schools, 13 principals, 226 teachers in Mashuuru District. They were targeted since they were stakeholders to planning, integrating and evaluating ICT infrastructures, projects in their respective schools.

\section{SAMPLE SIZE AND SAMPLING TECHNIQUE}

According to [44], a sample is a group of subjects or situations selected from a population. Sampling therefore is the act, process, or technique of selecting a suitable sample, 
or a representative part of a population for the purpose of determining parameters or characteristics of the whole population. According to [44] a sample of (30\%) will be appropriate in social science study. In this study the sample used was: 88 teachers as a result of sampling out (30\%), all the 13 principals, and all the 13 schools in Mashuuru District irrespective of their category.

\section{RESEARCH INSTRUMENTS}

The data collection instruments included in-depth interview with the school Principals and questionnaire for both Principals and teachers. The questionnaire items comprises of both close-ended and open-ended questions, as well as matrix items that give the advantage of collecting both qualitative and quantitative data to generate maximum required information.

\section{E. VALIDITY OF THE INSTRUMENTS}

Validity indicates the degree of accuracy of the measuring instrument used, that is measure what it is suppose to measure Therefore, relevant, free of bias, reliable and available [45]. Based on analysis of the sample study results, rectification was made to the research instruments. The researcher's supervisors helped the researcher to assess the concepts that the instruments were to measure in order to determine whether the set of items accurately represents the items under study. An average index found was 0.761 and this was above 0.7 hence the instrument was accepted as valid as suggested [46].

\section{F. RELIABILITY OF THE INSTRUMENT}

A correlation coefficient was adopted which indicated the reliability of the instrument used. The scores were correlated using Pearson's Product Moment Coefficient and this was taken as an estimate of reliability. The coefficient of 0.74 was attained, therefore, the instruments were adopted for use in the study and otherwise necessary adjustments would have been made to the research instruments [46]

\section{G. DATA ANALYSIS TECHNIQUES}

The data collected was coded and entered in the computer for analysis using the Statistical Package for the Social Sciences (SPSS) version 21 for windows since SPSS is able to handle large amount of data, and given its wide spectrum of statistical data presentation and analysis.

The data was presented using frequency percentages, tables and pie charts analyzed according to the theme in the objectives. Regression analysis was then used to show the extent at which independent variables influenced the dependent variable. Correlation analysis was done to establish the relationship between independent variables.

\section{RESULTS AND DISCUSSION}

\section{A. AGE OF THE RESPONDENTS}

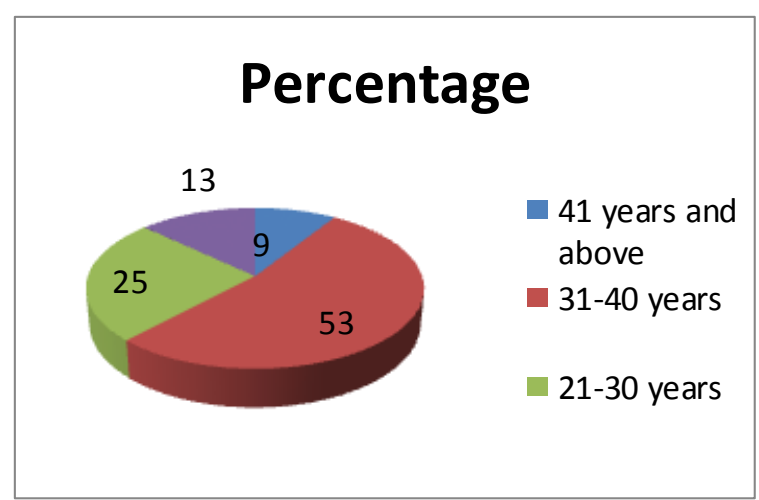

Figure 1: Gender of the respondents

The study shows that majority of the respondents were between the age bracket of 31-40 years (53\%) followed by those between the age bracket of 21-30 years (25\%). Those above 41 years were only (9\%) while those below 20 years were $(13 \%)$. This is an indication that most teachers in Mashuuru District Secondary Schools were between the age bracket of 21-40 years implying that they left college recently during the computer era. Therefore, they could have possibly come across basic computer training courses hence knowledgeable in ICT basics like Microsoft suit. The findings are in line with [3] who observed that young teachers in secondary schools have the advantage over old teachers in the use of ICT because they have gone through college education during the computer era. This has exposed them to various ICT knowledge and facilities even the most detached teachers from technology possibly are likely to have an idea or two about ICT.

\section{B. WORK EXPERIENCE}

The work experience of the respondents was investigated.

Table 1: Age of the respondents

\begin{tabular}{|c|c|c|c|}
\hline & Frequency & Percent & $\begin{array}{r}\text { Valid } \\
\text { Percent }\end{array}$ \\
\hline $\begin{array}{l}\text { Less than } \\
1 \text { year }\end{array}$ & 14 & 15.9 & 15.9 \\
\hline $2-5$ years & 30 & 34.1 & 34.1 \\
\hline $\begin{array}{c}\text { 6-10 } \\
\text { years }\end{array}$ & 32 & 36.4 & 36.4 \\
\hline $\begin{array}{l}11 \text { years } \\
\text { and above }\end{array}$ & 12 & 13.6 & 13.6 \\
\hline Total & 88 & 100.0 & 100.0 \\
\hline
\end{tabular}

The study further established that teachers who had worked 6-10 years were the majority $(36 \%)$ followed by those who has worked for 2-5 years (34\%). Teachers who had worked for more than ten years were $14 \%$ and those who were still 
new in the teaching profession were (16\%) who had taught for less than one year. This shows that about half of the respondents had worked for over five years thus had enough experience in schools to provide reliable information.

\section{PERCEPTION OF TEACHERS ON THE USE OF ICT IN RESOURCE PLANNING}

The first objective of the study aimed at finding out the influence of the teachers' perception on the integration of ICT in resource planning in schools. Perception and attitude towards ICT use play a pivotal in determining whether teachers will integrate ICT in schools. Positive attitude will enhance high utilization of ICT. The study first established the perception of teachers in the use of ICT in resource planning in schools and the results are shown in table 2 below.

Table 2: Perception of teachers on the use of ICT in resource planning

\begin{tabular}{|l|l|l|l|l|c|}
\hline Variable & $\mathrm{N}$ & Min & Max & Mean & Std. Deviation \\
\hline Saves time & 88 & 1.00 & 4.00 & 3.28 & 0.93 \\
Tasks & 88 & 1.00 & 4.00 & 3.23 & 0.98 \\
Lesson preparation & 88 & 1.00 & 4.00 & 3.22 & 0.86 \\
Like it & 88 & 1.00 & 4.00 & 3.11 & 0.88 \\
Producing reports & 88 & 1.00 & 4.00 & 3.08 & 1.09 \\
Not hectic & 88 & 1.00 & 4.00 & 2.82 & 1.11 \\
Accomplishing much & 88 & 1.00 & 4.00 & 2.80 & 1.08 \\
\hline
\end{tabular}

Table 2 reveals that the respondents had moderate positive of perception towards the integration of ICT in resource planning in school. Teachers perceived that ICT saves time, helps them accomplish many tasks within a short time, eases lesson preparation, teachers generally like it, is efficient in producing reports, it is not hectic nor complicated to use and helps them accomplish much within a short times with a mean level of $3.28,3.23,3.22,3.11,3.08,2.82$ and 2.80 respectively. The average mean was 3.08 implying a moderate level of positive perception among the teachers on the use of ICT in resource planning of the school. According to [11], teachers' Perception towards new technologies in secondary schools and its effects in integration and use shows that if teachers perceive use of ICT as either satisfying their own needs or their students' needs, it is likely they would implement it in school. Attitude is brought about by other factors like teachers' competency, skills, knowledge and perception towards ICT.

Table 3: Coefficient of Determination - R2 Combined

\begin{tabular}{|c|c|c|c|}
\hline $\mathrm{R}$ & R Square & $\begin{array}{l}\text { Adjusted } \mathrm{R} \\
\text { Square }\end{array}$ & \begin{tabular}{|lr} 
Std. Error \\
of & the \\
Estimate & \\
\end{tabular} \\
\hline $.206^{\mathrm{a}}$ & .043 & .031 & .80198 \\
\hline
\end{tabular}

The regression model's adjusted R-squared was 0.043 as indicated in table 3 above. The model therefore explains $(4.3 \%)$ of resource planning as influenced by teachers' perception as an independent variable. This therefore translates to the eight independent variables (saves time, performance of multiple tasks, lesson preparation, teachers love of ICT, producing reports, ICT being easy to use and accomplishing much work in a short time) which explain $(4.3 \%)$ of the teachers' perception factors influencing integration of ICT in resource planning in schools. Therefore, the remaining $58.8 \%$ is explained by other factors. The little influence of teachers' perception on ICT interaction could be as a result of other factors that influence perception like motivation from principals among other factors. That is why there is always mixed results on this subject matter. [36] argue that teachers' perceptions are influenced by their acceptance of the usefulness of ICT and its implementation in schools. A survey by EU School net in 2010 [33] involving teachers' use of ICT in six European Union countries, revealed that a large number of participants perceived use of ICT had positive impact on their learning, elicited interest, promoted individualized learning and helped to lengthen study beyond school day. However, a study by [34] suggested that small number of teachers perceived benefits of ICT in schools were not clearly identified. Some teachers viewed ICT as waste of time.

In line with this, [33] notes that, regardless of the amount of technology and sophistication, technology will not be used unless school managers and teachers have the skills, knowledge and attitude necessary to infuse it into the curriculum and other school management processes and procedures. Perception of teachers towards the use of ICT thus remains a predetermining factor towards ICT use in schools. The findings thus indicate that perception in Mashuuru district accounts to only (4\%) implying that little has been done to change the attitude of teachers towards ICT use in schools.

\section{INFLUENCE OF PRINCIPAL AGE ON THE INTEGRATION OF ICT IN RESOURCE PLANNING IN SCHOOLS}

The second objective of the study aimed at finding out the influence of principal age on the integration of ICT in resource planning in schools. The results are indicated below.

Table 4: Coefficient of Determination - R2 Combined

\begin{tabular}{|l|l|l|c|}
\hline $\mathrm{R}$ & R Square & $\begin{array}{c}\text { Adjusted } \\
\text { Square }\end{array}$ & $\begin{array}{c}\text { Std. Error of } \\
\text { the Estimate }\end{array}$ \\
\hline $.468^{\mathrm{a}}$ & .219 & .210 & .86316 \\
\hline
\end{tabular}

The regression model's adjusted R-squared was 21.9 as indicated in table 4 below. The model therefore explains (21.9\%) of resource planning as influenced by the age of the 
principle as an independent variable. This therefore explains $(21.9 \%)$ of the principle's age factor affecting ICT integration in resource planning including; availing teaching resources, planning for infrastructure, attending to teachers' needs, preparing reports for teachers consumption, encouraging use of ICT and organizing for teachers training in ICT. Therefore, the remaining $(36.9 \%)$ should be explained by other factors possibly not captured in this study.

According to [30] the probability that teachers would use ICT in the classroom was limited by the reality that teachers who were educated 20 years ago were trained by people who themselves were trained before the arrival of computers in schools. Commenting on the same, Moreover, [39] found out in a study that decisions of younger workers were more strongly influenced by their attitude toward using the new technology. In contrast, older worker were more strongly influenced by subjective norm and perceived behavioral control. Then, these groups of people adopt very different decision processes in evaluating new technologies. On the other hand, [40] found that age was not a significant factor in relation to teachers' attitudes towards ICT.

Table 5: Significant Differences Between the groups

\begin{tabular}{|c|c|c|c|c|c|c|}
\hline & & Sum of Squares & df & $\begin{array}{l}\text { Mean } \\
\text { Square }\end{array}$ & $\mathrm{F}$ & Sig. \\
\hline \multirow{3}{*}{$\begin{array}{l}\text { Availability of } \\
\text { Infrastructure }\end{array}$} & Between Groups & 3459.648 & 41 & 84.382 & \multirow[t]{3}{*}{3.430} & \multirow[t]{3}{*}{.000} \\
\hline & Within Groups & 1131.625 & 46 & 24.601 & & \\
\hline & Total & 4591.273 & 87 & & & \\
\hline \multirow{3}{*}{$\begin{array}{l}\text { Teachers' } \\
\text { Training }\end{array}$} & Between Groups & 1621.825 & 41 & 39.557 & \multirow[t]{3}{*}{2.381} & \multirow[t]{3}{*}{.002} \\
\hline & Within Groups & 764.175 & 46 & 16.612 & & \\
\hline & Total & 2386.000 & 87 & & & \\
\hline \multirow{3}{*}{$\begin{array}{l}\text { perception of } \\
\text { Teachers }\end{array}$} & Between Groups & 1173.214 & 41 & 28.615 & \multirow[t]{3}{*}{1.505} & \multirow[t]{3}{*}{.089} \\
\hline & Within Groups & 874.683 & 46 & 19.015 & & \\
\hline & Total & 2047.898 & 87 & & & \\
\hline \multirow{3}{*}{$\begin{array}{l}\text { Principal } \\
\text { Age }\end{array}$} & Between Groups & 50.455 & 41 & 1.231 & \multirow[t]{3}{*}{1.790} & \multirow[t]{3}{*}{.028} \\
\hline & Within Groups & 31.625 & 46 & .688 & & \\
\hline & Total & 82.080 & 87 & & & \\
\hline
\end{tabular}

The results in Table 5 below reveal that there are significant differences in the responses for the three variables, availability of infrastructure (0.000), level of teachers' training in ICT (0.002), perception of teachers (0.089) and principle's age (0.028). The differences in the mean responses from the groups could be as a result of management planning and implementing issues without proper consideration and consultation with the teachers and non teaching staff members of the schools as revealed in the open ended questions. Another possible reason would be because the teachers have actually allowed the non teaching staff to do ICT related tasks for them. Hence, the teachers are not aware of what exactly the management is doing in terms of implementation of ICT in resource planning in schools. It could also mean that the schools have many teachers with ICT skills, but do not bother to utilize ICT infrastructure in the planning of the resources both in and outside class.

\section{CONCLUSION AND RECOMMENDATION}

\section{A. CONCLUSION}

Based on the study findings, the study concluded that perception of teachers towards ICT integration had an influence. This implies that, provided ICT is available, teachers are trained and the principals have the good will, teachers are likely to employ ICT in resource planning in schools. Generally, it was concluded that availability of ICT infrastructure, training and principals' age greatly influenced the integration of ICT in resource planning in schools.

\section{B. RECOMMENDATIONS}

Based on the findings, the study recommended the following:

i. Since the principal's age play a great role in influencing ICT integration in schools, there is need for the education ministry to make sure that more young principals trained in ICT take the managerial leadership in schools. This will help provide an environment where teachers and the rest of the school workers are encouraged to use ICT in resource planning.

ii. The challenge of electricity was cited as one of the hindrances to the integration of ICT in schools. There is need therefore for the government to make sure that all secondary schools are provided with adequate and constant electricity.

iii. Teachers should also endeavor to buy their own computers and laptops so that they can improve on the art of ICT usage in resource planning.

iv. Moreover, there is need for the Ministry of Education to develop ICT content since there is still the challenge of inadequate content especially in regard to resource planning and curriculum development.

v. There is need to carry out further research to establish other factors influencing ICT integration in resource planning in secondary schools. 


\section{Factors Influencing ICT Integration in Resource Planning In Secondary Schools in Mashuuru District, Kajiado County, Kenya}

\section{ACKNOWLEDGEMENT}

I am grateful and deeply indebted to my family and friends whom this work would have been impossible without their material support. First of all, I thank Almighty God for bringing me this far and providing me with wisdom, guidance, strength and more so focus that has helped me to make the project journal a success. I would like to express my most sincere gratitude to my University supervisors Dr Rose Obae (Senior lecturer) and Mr. Ferdinand Mbeche (Lecturer) from university of Nairobi for their guidance and encouragement in preparation of this research journal. To all who made this work a success, I thank you all.

\section{REFERENCES}

[1]. FAWE, "Integration of IT in Schools. Report number 3. (pp 56). Nairobi. Kenya: Self"' (2015).

[2]. C. Tuysuz, "The Effects of Virtual Laboratory on Students' Achievement and Attitude in Chemistry". Int. Online J. on Educ. Sci., (2010), 2(1), 37-53.

[3]. R. Kiilu, "An E-Learning Approach to Secondary School Education”: EReadiness Implications in Kenya". Masinde Muliro University. Retrieved October, 2015 from http://www.iiste.org/Journals/index.php/JEB/article/viewfile/3707/3756

[4]. Government of Kenya, " ICT Capacities and Capabilities in Secondary Schools in Kenya 2009/2010", NCST No: 046, Nairobi, Kenya: Government Printer.

[5]. J. Keengwe, and G. Onchwari, "Computer Technology integration and student learning: Barriers and promise". Journal of Science Education and Technology,(2011), 17, 560-570.

[6]. M. N. Amutabi, "Challenges facing the use of ICT in Kenyan Universities". UNESCO Forum Colloquium on Research and Higher Education Policy 1-3 December 2004, (2012).

[7]. U.V. Reddi, "Role of ICTs in Education and Development: Potential, Pitfalls and Challenges" (2011). Retrieved from http:www.unesco.org/education/aladin/pdf/cpourseol /unit-13pdf

[8]. J.O., Oguta, R.K.W. Egessa, and D. Musiega, "Effects of Information Communication and Technology (ICT) Application on Strategic Educational Quality Standards Management in Bungoma County, Kenya." International Journal of Business and Management Invention, (2014), 3(5), 11-17.

[9]. P. Ngugi, An Investigation into the Extent of use of ICT in Education Management Ministry of Education, (2009). National Information and Communication Technology (ICT) for Education and Training. Nairobi: Acts Press in Public Secondary Schools in Naivasha District, K.U. (2012).

[10]. J. Manduku, A. Kosgey, and H. Sang, "Adoption and use of ICT in enhancing management of public secondary schools: A survey of Kesses zone secondary schools in Wareng District of Wasin Gishu County, Kenya" (2012).

[11]. NEPAD e-Africa Commission, "The NEPAD e-Initiative: Ensuring that Young Participate Actively in the Global Information Society and Knowledge Economy" (2013).. Retrieved on October 22, 2015 from http//wwwnet.eafricacommission.org.

[12]. W. Chigona, "School-level ICT Integration Factors in the Western Cape Schools. Department of Information Systems, University of Cape Town". Proceedings of Fourth IEEE International Workshop on Technology for Education in Developing Countries, 10-12 July, Iringa Tanzania, (2006). pp. $57-61$.
[13]. E. Mentz, "Managing technology integration in schools: A South African perspective." Journal of Educational Administration, (2010), vol. 41(2), 186-200.

[14]. M. Koehler, "Pedagogical Content Knowledge Posted in Core" 2011. Retrieved on 13th May 2014 from http://mkoehler.educ.msu.edu/tpack/cate gory/core/

[15]. T. M. Waema, "A brief History of the Development of ICT Policy in Kenya at the crossroads: ICT policy making in East Africa". Nairobi, Kenya: East African Educational Publishers Ltd (2005).

[16]. D. K., Meryo, and J. M. Boit, "The Challenges of using Information Communication Technology in School Administration in Kenya." Moi University. (2012).

[17]. K. Abdullah, "Barrier to successful integration of ICT in teaching and learning environment." A review of Literature. University of Bandoora Vic Australia. Eurasia Journal of Mathematics Science and Technology, (2009), 5(3) 235-245.

[18]. A. Albirini, "The crisis of educational technology, and the prospect of reinventing education." Educational Technology\& Society, (2007), 10 (1), 227-236.

[19]. R., Roberts, and J. Sikes, "How IT is managing new demands: Mckinsey Global Survey Results". Mckinsey on Business Technology, 22(2011), 24-33.

[20]. E. Makhanu, and G. Kamper, "The relationship between Principals Access to Information and Communication Technology (ICT) and School Performance in Kenya." University of South Africa, Pretoria 003. Retrieved June, 2015 from http://www.heraldjournals.org/hjegs/archive.htm

[21]. D.W. Maguire, "The use of clusters to build an ICT industry, informing science InSITE - Where Parallels Intersect." June 2003 Edith Cowan University, Perth, Western Australia, (2003). allmaguires@bigpond.com.au.

[22]. S. Chepkonga, "Training needs assessment of principals in financial management. Published Master's thesis, German, Saarbrucken: LAP Lambert Academic Publishing" (2012).

[23]. M. Sanja, and K. Rabah, "Emerging Trends in Computing and Information Sciences." CIS Journal. All rights reserved. Vol. 4, No. 11 November 2013 ISSN 2079-8407.

[24]. A. Winkelmann, and C. Leyh, "Teaching ERP systems: A multi-perspective view on the ERP system market." Journal of Information Systems Education, (2013), 21(2), 233-242.

[25]. L., Makewa, E. Role, and R. Nyamboga, "Teacher evaluation of the Principal's leadership characteristics related to computer studies implementation in Rongo District, Kenya." International Journal of Education and Development using Information and Communication Technology (IJCDICT), (2011), 7(2), 5-14.

[26]. G. Cohen, and I. Salomon, "Information-communication technology (ICT) and transport: does knowledge underpin policy?" Telecommunications Policy, (2011), Vol. 26, pp. 31-52.

[27]. P. Tearle, " The Implementation of Information and Communication Technology in United Kingdom Secondary Schools". (2008). Final Report, University of Exeter, Exeter.

[28]. Republic of Kenya, "ICTs in Education Options". Paper, Ministry of Education, Science and Technology Draft 16th June, 2005.

[29]. UNESCO, "The UNESCO ICT in education programme". United Nations Educational, Scientific and Cultural Organization (UNESCO): Bangkok (2015).

[30]. M. Kandiri, "A survey on ICT Access and use in Kenya secondary schools". Summit strategies ltd, Nairobi Kenya. (2012).

[31]. Government of Kenya, "National ICT Policy, Ministry of Information and Communication". Government printers, Nairobi, Kenya (2015). 
[32]. S.S. Olanipekun, “Appraisal of Nigerian senior secondary school's English language curriculum in the light of modern curriculum". Advances in Arts, Social Sciences and Educational Research, (2013), vol. 3(7), $527-532$.

[33]. B. Andoh, “An exploration of Teachers' skills, perceptions and practices of ICT in teaching and learning in the Ghanaian second-cycle schools". Contemporary education technology, (2012), 3(1) 36-49.

[34]. W., Korte, and T. Husing, "Benchmarking Access and Use of ICT in European Schools 2006: Results from Head Teacher and A Classroom Teacher Surveys in 27 European Countries”. Empirica. (2006). 1.

[35]. M. Drent, and M. Meelissen, "ICT factors stimulating teachers educators to use ICT innovatively". Computers \& Education, (2013), 51 (1) $187-199$

[36]. J. E. Woodrow, "The influence of programming training on the computer literacy and attitudes of pre-serviceteachers". Journal of Research on Computing in Education (1992), 25(2), 200-219

[37]. T. Teo, "Pre-service teachers' attitudes towards. computer use: A Singapore survey". Nanyang Technological University (2012)

[38]. D. Ncunge, M. Sakwa, and W. Mwangi, "Weeks". Accessed on 19th April 2016 from http://www.the-star.co.ke/news/2016/02/05/power-for-all-primary-scho ols-in-two-weeks c1289248

[39]. J. Peeraer, and P. Petergem, "ICT in teacher education in an emerging developing country: Vietnam's baseline situation at the start of the year of ICT". Journal of Computers \& Education 56(2011) 974-982.

[40]. W., Khan, and H. M. Inamullah,. "A Study of Lower-order and Higher-order Questions at Secondary Level”. Asian Social Science, (2011), 7(9)

[41]. M.A Ewumi, "Gender and Socio-Economic Status as Correlates of Students' Achievement in Senior Secondary Schools". European Science Journal, (2011), 8(4): 23-36.

[42]. J. A. Orodho, "Techniques of writing research proposal and reports in education and social sciences". Kanezja, Maseno, Kenya, (2009).

[43]. C. R. Kothari, “Research methodology: Methods and techniques”. New Delhi. New Age International (P) Limited publishers (2003).

[44]. O. M. Mugenda, and A. G. Mugenda, "Research Methods. Qualitative and quantitative approaches”. Nairobi: acts press (1999).

[45]. C., McGarty, and A. Haslam, "Research Methods and Statistics in Psychology" (SAGE Foundations of Psychology series) 2nd Edition ((2003).

[46]. M. E. Amin, "Special Science Research: Conception, methods and analysis. Kampala: Makerere University Printer, (2005). 